\section{EKONOMSKI I DRUŠTVENI TROŠKOVI OVISNOSTI O KOCKANJU U HRVATSKOJ - DRUGA STRANA MEDALJE}

Izvorni znanstveni članak

Primljeno: prosinac, 2020.

Prihvaćeno: veljača, 2021. UDK: 613.8:794.9

DOI 10.3935/jsr.v28i1.413

Tomislav Globan ${ }^{1}$

orcid.org/0000-0001-5716-2113

Sveučilište u Zagrebu

Ekonomski fakultet

Lucija Rogić

Dumančić ${ }^{2}$

orcid.org/0000-0002-7963-4166

Sveučlišste u Zagrebu

Ekonomski fakultet

Neven Ricijaš ${ }^{3}$

orcid.org/0000-0001-8107-8448

Sveučilište u Zagrebu

Edukacijsko-rehabilitacijski

fakultet

Mislav Ante

Omazić ${ }^{4}$

orcid.org/0000-0001-5704-0108

Sveučilište u Zagrebu

Ekonomski fakultet

Ključne riječi:

kockanje;

ovisnost o kockanju;

ekonomski trošak;

društveni trošak; posljedice 
koristilo originalne i strože kriterije prevalencije ovisnosti o kockanju, a neovisno o korištenoj metodologiji izračuna, rezultati pokazuju da društveni troškovi ovisnosti o kockanju u Hrvatskoj čine između 34\% i 77\% ukupnih godišnjih prihoda od igara na sreću.

Rezultati su interpretirani u kontekstu općih smjernica za unaprjeđivanje politika odgovornog priređivanja igara na sreću, a s ciljem smanjivanja vjerojatnosti razvoja štetnih psihosocijalnih posljedica.

\section{UVOD}

Kockanju se kroz povijest pristupalo na različite načine, odnosno iz različitih stručnih perspektiva, kao i znanstvenih disciplina. Na našim prostorima, najčešća su istraživanja u području društvenih znanosti (edukacijsko-rehabilitacijske znanosti, psihologija, socijalne djelatnosti, sociologija) te medicinskih znanosti (psihijatrija). Ekonomska istraživanja nešto su rjeđa te se uglavnom radi o ekonomskim analizama ostvarenih prihoda temeljem djelatnosti igara na sreću (Lovrinčević, Mikulić i Orlović, 2015.; Šimović i sur., 2019.).

U Hrvatskoj je priređivanje igara na sreću, odnosno kockarskih proizvoda i usluga, temeljno regulirano Zakonom o igrama na sreću (2009., 2013., 2014.; u daljnjem tekstu: Zakon) i pripadajućim pravilnicima, pri čemu su dostupne igre kategorizirane $u$ četiri skupine: (1) lutrijske igre, (2) igre u kasinima (3) igre klađenja i (4) igre na sreću na automatima (čl. 5). Zakon predviđa i online modalitet igranja (igranje na daljinu), odnosno priređivanje igara na sreću putem interneta, telefona ili nekih drugih interaktivnih komunikacijskih uređaja putem kojih igrač može odigrati igru samostalno, kroz interakciju sa sustavom, bez neposrednog priređivača (čl. 4, st. 21). Cjelokupni regulatorni model priređivanja igara na sreću u Hrvatskoj, iz javnozdravstvene perspektive, nije dovoljno kvalitetno postavljen u području zaštite mentalnog zdravlja (više u Ricijaš, Maglica i Dodig Hundrić, 2019.), te uz probleme prevelike dostupnosti i pristupačnosti igara na sreću (Ricijaš i sur., 2016.), bilježimo i probleme nedovoljno razrađenih standarda odgovornog priređivanja igara na sreću (primjerice, u kontekstu oglašavanja, komercijalne komunikacije s igračima, online platformi za igranje, postupka samoisključivanja i druge). Navedeno se reflektira i na vjerojatnost, odnosno društveni potencijal za razvoj ovisnosti o kockanju.

Suvremenim pristupom ovisnostima više ne podrazumijevamo samo unošenje psihoaktivne tvari u organizam (legalnog ili ilegalnog karaktera), već se posljednjih desetak godina značajno razvilo područje znanstvenog izučavanja i kliničkog rada u području bihevioralnih ovisnosti. Ovisnost o kockanju (eng. gambling disorder) je, pod ovim nazivom, uvrštena u službenu klasifikaciju bolesti 2013. godine u revidiranom petom izdanju Dijagnostičkog i statističkog priručnika za duševne poremećaje 
Američke psihijatrijske udruge (DSM-5, 2014). Naravno, psihosocijalni problemi povezani s kockanjem postojali su i do tada, ali se poremećaj nazivao "patološko kockanje», iako je znanstvena literatura već koristila pojam "ovisnost o kockanju« (eng. gambling addiction). Ono je od strane Američke psihijatrijske udruge formalno priznato kao psihički poremećaj 1980. godine, najviše zahvaljujući radu dr. Roberta Custera koji se bavio liječenjem patoloških kockara, te je ono uvršteno u treće izdanje DSM-a (Bodor, 2018.). U predloženim kliničkim kriterijima naglasak je bio stavljen na progresivni gubitak kontrole nad kockanjem, uz navođenje sedam odrednica kojima se opisuju individualni, obiteljski, socijalni i financijski aspekti ove dijagnoze. $U$ još uvijek aktualnom desetom izdanju Medicinske klasifikacije bolesti - MKB-10 (na snazi do 1. 1. 2022. kada će MKB-11 stupiti na snagu ${ }^{5}$, op. autora) problematično kockanje naziva se "patološko kockanje« te je klasificirano u skupinu poremećaji navika i nagona, pod šifrom F63. MKB-11 govori o skupini poremećaja uzrokovanih konzumacijom psihoaktivnih tvari ili ovisničkim (adiktivnim) ponašanjem, unutar koje skupine se nalazi podskupina poremećaja vezana uz adiktivna ponašanja, a pod šifrom 6C50 definirana je ovisnost o kockanju, odnosno gambling disorder (izraz je zadržan u engleskom izvorniku s obzirom da još ne postoji službeni hrvatski prijevod nove klasifikacije bolesti MKB-11, op. autora). On je karakteriziran obrascem perzistentnog ili ponavljajućeg kockanja koje može biti online (putem interneta) ili offline (zemaljsko), a manifestirano s: (1) narušenom kontrolom oko kockanja (primjerice, početkom, učestalosti, intenziteta, duljine, prekida, konteksta i slično), (2) pojačanim prioritetom koji se daje kockanju u odnosu na druge životne interese i dnevne aktivnosti te (3) nastavkom ili eskalacijom kockanja unatoč pojavi negativnih posljedica koje se očituju na osobnom, obiteljskom, društvenom, obrazovnom ili drugom planu funkcioniranja. Pritom se u MKB-11 navodi da obrazac može biti kontinuiran ili epizodičan ili ponavljajući, a ponašanje mora biti prisutno barem 12 mjeseci za postavljanje dijagnoze, iako dozvoljava i kraći period ukoliko su zadovoljeni svi dijagnostički kriteriji i simptomi su ozbiljno izraženi.

Danas postoje različiti pristupi procjeni i definiranju razina ovisničkog/patološkog, odnosno problematičnog/ekscesivnog obrasca ponašanja u području kockanja. Kao okvir za definiranje simptoma bihevioralnih ovisnosti, pa tako i ovisnosti o kockanju, najčešće se koristi Griffithsovih (2005.) šest kriterija: (1) preokupiranost tim ponašanjem, (2) uključivanje u ponašanje radi modifikacije raspoloženja, (3) razvoj tolerancije u dosadašnjim manifestacijama ponašanja, (4) razvoj simptoma sustezanja u odsutnosti ponašanja, (5) sukobi s drugima kao posljedica uključenosti u ponaša-

5 World Health Organisation - WHO (2018). WHO releases new International Classification of Diseases (ICD 11). Dostupno na: https://www.who.int/news-room/detail/18-06-2018-who-releases-new-international-classification-of-diseases-(icd-11) (15.12.2020.). 
nje te (6) relaps, odnosno nemogućnost samostalnog ostvarivanja apstinencije od navedenog ponašanja. Postojanje jasnih kriterija procjene problema nužno je iz tri međupovezana razloga: (1) razvoj instrumenata procjene, (2) klinička procjena i postavljanje dijagnoze te (3) provođenje znanstvenih istraživanja u području kockanja i ovisnosti o kockanju.

Kako bismo dobili kvalitetnu i znanstveno utemeljenu sliku o incidenciji i prevalenciji problema povezanih s kockanjem unutar populacije, nužno je imati kvalitetne instrumente procjene. Oni se posebno razvijaju posljednjih dvadesetak godina, te je danas dostupan niz instrumenata. Međutim, samo nekoliko njih ima visoke metrijske karakteristike te su se dugogodišnjim međunarodnim transverzalnim i longitudinalnim istraživanjima dokazali kao tzv. "zlatni standard " (Petry i Armentano 1999.; Arthur i sur., 2008.; Holtgraves, 2009.; Miller i sur., 2013.; Calado i Griffiths, 2016.; Caler i Nower, 2016.; King i sur. 2020.). Radi se o sljedećih osam instrumenata koji se koriste za odrasle osobe, pri čemu su zadržani engleski nazivi i kratice, budući da nisu svi prevedeni i korišteni u hrvatskom znanstvenom prostoru: (1) South Oaks Gambling Screen (SOGS), (2) Problem Gambling Severity Index (PGSI), (3) DSM-IV kriteriji za patološke kockanje ili DSM-5 kriteriji za ovisnost o kockanju, (4) Diagnostic Interview Schedule (DIS) za patološko kockanje, (5) Diagnostic Interview for Gambling Severity (DIGS), (6) National Opinion Research Center DSM Screen for Gambling Problems (NODS), (7) Gamblers Anonymous Twenty Questions (GA20) i (8) Lie/Bet scale. Pritom je važno naglasiti kako svaki instrument ima specifičan i jedinstven način mjerenja psihosocijalnih problema/posljedica kockanja, te da svaki ima svoje pragove u kategorizaciji rizičnosti, ali i specifične nazive za različite vrste problema. Međutim, iako su nazivi formalno različiti, najviši broj bodova uvijek upućuje na ozbiljne psihosocijalne probleme ovisnosti o kockanju. U nekim instrumentima se ono zove "patološko kockanje«, u nekima "vjerojatno patološko kockanje», zatim "problematično kockanje», dok neki instrumenti navode »visokorizično kockanje uz gubitak kontrole«, »ovisnost o kockanju« i slično. Zajedničko svim instrumentima je mjerenje sljedećeg seta ključnih štetnih psihosocijalnih posljedica kockanja:

- financijski problemi uzrokovani kockanjem, posuđivanje novca, nepridržavanje financijskog plana

- zdravstveni problemi i subjektivna percepcija problema s kockanjem

- kritiziranje od strane drugih i konflikti zbog kockanja

- gubitak kontrole/samokontrole u području kockanja, lov gubitaka

- skrivanje kockanja od drugih, subjektivni osjećaj krivnje

- razvoj tolerancije i ekscesivnog ponašanja u području kockanja.

Slijedom navedenog, jasno je kako ovisnost o kockanju stvara niz štetnih psihosocijalnih posljedica koje se očituju u području zdravstvenog statusa osobe, finan- 
cijskih problema, ali i problema s rizičnim/kriminalnim ponašanjem, problemima u obiteljskom, poslovnom, obrazovnom funkcioniranju, kao i u području širih socijalnih odnosa. Međutim, potrebno je naglasiti da bez longitudinalnih studija nije moguće sa sigurnošću utvrditi uzročno-posljedične veze, iako ih logički modeli u pravilu mogu objasniti. Transverzalnim korelacijskim nacrtima dobivamo sliku o povezanosti među varijablama, ali njihov uzročno-posljedični odnos nije nužno objašnjiv. To je puno teže objasniti u području psiholoških posljedica, odnosno komorbiditeta s drugim duševnim poremećajima, budući da je za nešto suptilnije manifestacije poremećaja (primjerice, blaži emocionalni poremećaji, slabije vidljivi poremećaji ličnosti i slično), teško odrediti jesu li postojali i prije razvoja ovisnosti o kockanju.

Kako bi se ovaj problem nadišao, osim longitudinalnim istraživačkim nacrtima, rađena su istraživanja i metodom tzv. temporal sequencing, odnosno vremenskog određivanja redoslijeda pojave pojedinih problema mentalnog zdravlja u odnosu na ovisnost o kockanju. Jedno takvo istraživanje proveli su Sundqvist i Rosendahl (2019.) u Švedskoj na općoj populaciji građana, a dodana vrijednost je u tome što su diferencirano promatrali komorbiditet problema povezanih s kockanjem u odnosu na spol/ rod. Njihovi rezultati pokazuju kako i muškarci i žene koji imaju probleme povezane s kockanjem imaju dva i više puta veći rizik razviti komorbiditet drugih problema mentalnog zdravlja u odnosu na kontrolnu skupinu, odnosno redovnu populaciju koja nije razvila probleme. Posebno se ističu problemi s alkoholom za koje je tri puta veća vjerojatnost razvoja i kod muškaraca i kod žena. Autori su također našli značajne rodne razlike. Kod žena su se problemi povezani s kockanjem počeli javljati nakon što su već doživjele prve probleme anksioznosti, depresije i konzumacije psihoaktivnih tvari, dok se kod muškaraca raniji simptomi nisu pojavljivali. Drugim riječima, muškarci u značajno većoj mjeri razvijaju druge simptome i probleme mentalnog zdravlja kao posljedicu problema povezanih s kockanjem (nakon ovisnosti o kockanju), a najčešći su depresija i suicidalnost. U odnosu na dob početka kockanja i pojave problema, također su pronađene značajne razlike, na način da žene koje razviju probleme kasnije počinju kockati u odnosu na kontrolnu skupinu, dok kod muškaraca nema razlike između ispitivane i kontrolne skupine. Žene generalno kasnije počinju kockati u odnosu na muškarce. Ovakvi podaci su u skladu i s nekim drugim istraživanjima koja govore u prilog tezi da žene u većoj mjeri kockaju kako bi ublažile neke postojeće neugodne emocije (Ibáñez i sur., 2003.; Boughton i Falenchuk, 2007.; Desai i Potenza, 2008.).

Brojna korelacijska istraživanja potvrdila su značajan komorbiditet ovisnosti o kockanju s drugim zdravstvenim problemima (što uključuje i probleme mentalnog zdravlja), kao i problemima u socijalnom funkcioniranju. $U$ odnosu na osobine ličnosti, impulzivnost te izražena potreba za traženjem uzbuđenja, relativno su najkonzistentniji prediktori razvoja ekscesivnog kockanja (Canale i sur., 2015.; Browne 
i sur., 2019.), dok u odnosu na komorbiditet s drugim psihijatrijskim poremećajima, istraživanja najčešće mjere i navode ovisnost o nikotinu (60\%), alkoholu i drogama (58\%), poremećaje raspoloženja (38\%) i anksiozne poremećaje (37\%) (Lorains, Cowlishaw i Thomas, 2011.).

Metaanalizom (Dowling i sur., 2016.) 14 znanstvenih studija na temu obiteljskog zlostavljanja i zlostavljanja u partnerskim odnosima zaključeno je kako postoji značajna povezanost između problematičnog kockanja i postajanja žrtvom intimnog partnerskog nasilja. Više od jedne trećine kockara izjasnilo se da su bili žrtve intimnog partnerskog nasilja $(38,1 \%)$ ili da su sami počinili nasilje prema partneru/ici fizičkim zlostavljanjem (36,5\%), a prevalencija problematičnog kockanja kod obiteljskih nasilnika je $11,3 \%$. Partnersko nasilje u obiteljima ovisnika o kockanju povezano je više s mlađom dobi, problemima (ne)zaposlenosti, impulzivnosti, te zlouporabom alkohola i droga. Na sličan način, pozitivna povezanost između učestalosti kockanja, problema povezanih s kockanjem i kriminalnog ponašanja dokazana je i hrvatskim (Ricijaš, Dodig Hundrić i Kranželić, 2015.) i inozemnim istraživanjima. Tako se, primjerice, prevalencija kaznenih djela počinjenih od strane odraslih osoba (najčešće prijevare, krađe, preprodaja psihoaktivnih tvari, financijski kriminalitet, pronevjere i krivotvorenje), a sa svrhom financiranja kockarskih aktivnosti, kreće između 65 i 89\% (Magoon, Gupta i Derevensky, 2005.). Pregledom 27 studija u različitim zemljama koje su za cilj imale istraživanje obilježja kockanja zatvoreničke populacije, utvrđen je udio od čak 30\% problematičnih kockara (Williams, Royston i Hagen, 2005.).

Razlike u prevalenciji široke lepeze štetnih psihosocijalnih posljedica ovisnosti o kockanju dobro ilustriraju rezultati skupine 17 znanstvenika koji su za američku nacionalnu komisiju o utjecaju kockanja (eng. National Gambling Impact Study Commission) proveli veliko istraživanje pod nazivom "Studija utjecaja kockanja i ponašanja« (eng. Gambling Impact and Behavior Study). Istraživanje je provedeno na uzorku od N=2.417 američkih državljana koji ne kockaju, te onih koji kockaju, ali su razvili različite razine štetnih psihosocijalnih posljedica. Njihovi rezultati linearno pokazuju veću prevalenciju štetnih posljedica ovisno o intenzitetu simptoma ovisnosti o kockanju, pri čemu su najznačajnije razlike u području emocionalno štetnih obiteljskih konflikata, maničnih i depresivnih simptoma, ovisnosti o alkoholu/drogama, konzumaciji droga, gubitku posla, bankrotu, uhićenju i prizonizaciji.

Zaključno, referirat ćemo se na britanske autore koji su za potrebe britanskog Odbora za igre na sreću (eng. Gambling Commission), Odbora za strategije odgovornog kockanja (eng. Responsible Gambling Strategy Board) i GambleAware nevladine organizacije izradili okvir mjerenja šetnih posljedica kockanja (eng. gambling-related harms) (Wardle i sur., 2018.). Navedeni autori su u svojem izvještaju na sljedeći način definirali štetne posljedice kockanja, a koju preuzimaju i autori ovog rada: „Štetne 


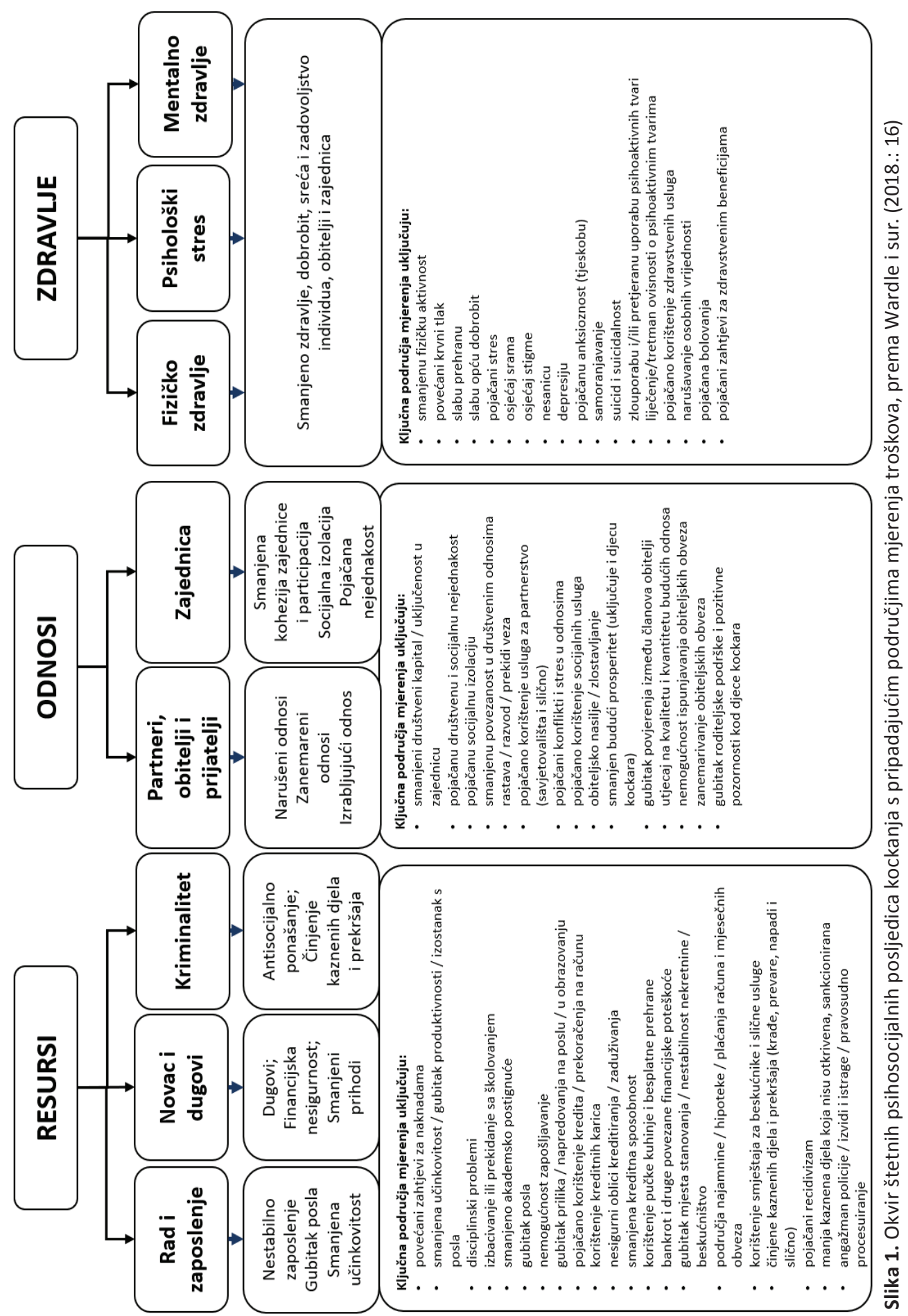


posljedice povezane s kockanjem su štetni učinci kockanja na zdravlje i dobrobit pojedinaca, obitelji, zajednica i društva. Pritom su te posljedice raznolike, utječu na resurse, odnose i zdravlje te mogu odražavati međudjelovanje između pojedinačnih, obiteljskih i društvenih procesa. Štetni učinci kockanja mogu biti kratkotrajni, ali i dugoročni, te tada imaju dugotrajne posljedice koje mogu pogoršati postojeće nejednakosti« (Wardle i sur., 2018.: 5). Shematski je okvir štetnih posljedica s područjima mjerenja prikazan na Slici 1.

Sve komponente navedenih psihosocijalnih posljedica stvaraju više ili manje direktne, odnosno indirektne troškove društvu, budući da iziskuju angažman i resurse državnog aparata, odnosno javnog sektora, u području sustava zdravstva, pravosuđa, socijalne skrbi i obiteljsko-pravne zaštite, dok s druge strane opterećuju gospodarsku produktivnost i ekonomiju. Društvene troškove ovisnosti o kockanju stručna i znanstvena literatura definiraju kao štetne posljedice koje snose druge osobe ili skupine, a kao rezultat neke ekonomske ili društvene aktivnosti za koju nisu odgovorne. Franzini (2007.) smatra primjerenim promatrati društvene troškove kao posljedicu kršenja društvenih prava. Analiza troškova i koristi (eng. cost-benefit analysis) svakog projekta ili policy odluke pretpostavljaju da se kao glavno analitičko oruđe koriste procjene njihovih financijskih, ekonomskih, društvenih i drugih učinaka. Cilj takvih analiza je identificirati $i$ kvantificirati sve potencijalne učinke mjera koje se vrednuju, a njihov konačan rezultat je prikaz neto učinaka analiziranih mjera te ocjena isplativosti njihova provođenja.

U ovom radu procjenjuje se više kategorija društvenih i ekonomskih troškova kockanja u Republici Hrvatskoj. Riječ je o troškovima povezanim s tržištem rada, financijskim troškovima, troškovima kriminala, obiteljskim i zdravstvenim troškovima. U tim kategorijama uključeni su troškovi duševnih boli i patnji članova obitelji, gubitka posla, osobnog bankrota, pada produktivnosti kao troška za poslodavca, troškovi zdravstvenih usluga zbog lošeg zdravlja ili liječenja mentalnih bolesti, naknada za nezaposlene, troškovi pravosudnog sustava zbog uhićenja i zatvorskih kazni, itd.

Postoje značajne otegotne okolnosti prilikom mjerenja društvenih troškova ovisnosti o kockanju. Aktivnosti povezane s kockanjem snažno su isprepletene s pitanjima emocija, morala, vrijednosti i stereotipa. Zbog toga kvantifikacija društvenih troškova ulazi u zonu arbitrarnosti te je podložna manipulacijama. Također, vrlo je teško procijeniti novčanu protuvrijednost, primjerice, patnje i duševnih boli djece supružnika, ili troška pada produktivnosti za poslodavca koje su rezultat kockarove ovisnosti o igrama na sreću (Macur i sur., 2008.).

U idealnom slučaju, fundamentalno pitanje mjerenja troškova nasuprot koristi od kockanja trebalo bi postaviti za svaki tip kockanja (vrstu igre) i trebalo bi uzeti u obzir ekonomske čimbenike poput usporedbe realnih troškova i ekonomskih transfe- 
ra, opipljivih i neopipljivih učinaka, izravnih i neizravnih efekata, sadašnjih i budućih vrijednosti (uzeti u obzir diskontiranje), te dobiti i gubitaka ostvarenih od strane različitih društvenih skupina u različitim okolnostima (National Research Council, 1999.). S druge pak strane, zbog izrazite dostupnosti svih vrsta igara u Hrvatskoj, kao i visoke interkorelacije u učestalosti igranja visoko-adiktivnih igara (Dodig i Ricijaš, 2011.; Ricijaš i sur., 2016.; Dodig Hundrić i Ricijaš, 2019.; Ricijaš, 2019.), to nije moguće napraviti za svaku vrstu igre ili kombinaciju preferiranih igara.

Društvene troškove ovisnosti o kockanju treba promatrati i u kontekstu sveobuhvatnog učinka koju aktivnost kockanja ima na društvo. Nažalost, broj istraživanja koji procjenjuje ove učinke relativno je malen i u globalnom, a ne samo u lokalnom (hrvatskom) kontekstu. Objektivne metodološke prepreke otežavaju donošenje definitivnih i nedvojbenih zaključaka, stoga se u procjenama moramo voditi određenim intervalima pouzdanosti. Drugim riječima, konačan izračun društvenih troškova kockanja bit će izražen u intervalu od blažeg do strožeg kriterija nekog pokazatelja, poput prevalencije ovisnosti o kockanju u općoj populaciji.

Slijedom navedenog, cilj ovog istraživanja je izračunati ekonomske i društvene troškove ovisnosti o kockanju u Republici Hrvatskoj, odnosno niza štetnih psihosocijalnih posljedica kockanja. Svrha je osigurati znanstveno utemeljene pokazatelje ekonomskih i društvenih troškova ovisnosti o kockanju u Republici Hrvatskoj kao platforme za poticanje pozitivnih regulatornih izmjena kojima bi se osiguralo balansirano tržište između profitabilnih i rizičnih elemenata djelatnosti igara na sreću, odnosno potaknuti djelovanje prema sveobuhvatnijem nacionalnom osnaživanju ključnih komponenti društveno odgovornog priređivanja igara na sreću.

\section{METODOLOGIJA}

Projekt pod nazivom »Ekonomski i društveni troškovi ovisnosti o kockanju u Republici Hrvatskoj« proveden je uz financijsku potporu Hrvatske lutrije, d.o.o., od siječnja do svibnja 2020. godine. Kao preduvjet za izračun ovih troškova, te razumijevanje financijskih učinaka na ukupnu dobit od djelatnosti igara na sreću, potrebno je paralelno koristiti nekoliko parametara i kriterija:

1. Imati prevalencijske podatke o zastupljenosti problematičnog kockanja/ ovisnosti o kockanju u odrasloj populaciji. U ovom istraživanju koristili smo podatke istraživanja o igranju igara na sreću u hrvatskom društvu koje je proveo Institut društvenih znanosti Ivo Pilar i Ured za suzbijanje zlouporabe droga Vlade Republike Hrvatske (Glavak Tkalić, Miletić i Sučić, 2017.).

2. Imati podatke o prihodima u državni proračun temeljem igara na sreću, gdje smo koristili službene podatke Ministarstva financija Republike Hrvatske. 
3. Imati jasnu metodologiju izračuna društvenih i ekonomskih troškova. U ovom istraživanju koristili smo dvije metodologije: (1) NORC (eng. National Opinion Research Centre) koju je razvila američka Nacionalna komisija za procjenu učinaka kockanja (NORC), te APC (eng. Australian Productivity Commission) koju je razvila Australska komisija za produktivnost (APC). Obje su najčešće korištene metode mjerenja troškova ovisnosti o kockanju u svijetu, a prema istraživanju Reitha (2006.), ova dva metodološka pristupa predstavljaju prekretnicu kod evaluacije društvenih i ekonomskih troškova ovisnosti o kockanju.

Istraživanje Glavak Tkalić, Miletić i Sučić (2017.) provedeno je na reprezentativnom uzorku od $\mathrm{N}=4.992$ građana od 15 do 64 godina života, korištenjem PGSI instrumenta procjene. Rezultati su pokazali da oko 9\% Hrvata ima neku razinu štetnih psihosocijalnih posljedica povezanih s kockanjem, točnije, 4,3\% niski stupanj problema, 2,9\% umjeren stupanj problema, 2,2\% visok stupanj problema, ovisno o bodovima ostvarenima na PGSI-u. Za potrebe provedbe ovog projekta, stupili smo u kontakt s autorima istraživanja, zatražili i dobili detaljnije prevalencijske podatke (izvan onih objavljenih u službenoj publikaciji, op. autora), a kako bismo imali: (a) podatke o prevalenciji problematičnog kockanja samo za odraslu populaciju, od 18 do 64 godine života, te (b) kako bismo društvene troškove mogli računati prema originalnoj PGSI klasifikaciji te strožoj, odnosno konzervativnijoj klasifikaciji.

lako je SOGS najčešće korišten instrument u posljednjih trideset godina, novija istraživanja usporedbe SOGS-a i PGSI-a pokazuju bolje metrijske karakteristike PGSI skale (Wynne, 2003.; Holtgraves, 2009.; Volberg i Williams, 2012.; Currie, Hodgins i Casey, 2013.), ali i značajno preklapanje rezultata korištenjem obiju mjera. Drugim riječima, PGSI ima dobru konvergentnu valjanost (Orford i sur., 2010.), a od 2001. kada je razvijen, korišten je u mnogim nacionalnim studijama, posebno u Kanadi, Australiji i Europi (Neal, Delfabbro i O’Neil, 2005.; Kavli i Berntsen, 2005.; McCready i Adlaf, 2006.; Ministry of Health, 2009.; Olason i Gretarsson, 2009.; Kristiansen i Jensen, 2011.). Stoga je njegova primjena kao referentnog okvira u ovom istraživanju i više nego opravdana, a ključne prednosti PGSI-a, osim ranije navedenih, su:

- kreiran je i validiran specifično kao kvantitativna mjera (indeks) težine problematičnog kockanja u općoj populaciji (Ferris i Wynne, 2001.)

- ima jasniju i više potvrđivanu jednofaktorsku/jednodimenzionalnu strukturu (Miller i sur., 2013.)

- ima bolji Cronbachov alfa koeficijent pouzdanosti, odnosno jaku unutarnju konzistenciju

- ima visoku test-retest pouzdanost 
- ima bolju korelaciju s mjerama učestalosti kockanja (kriterijska valjanost)

- koristi ljestvicu odgovora od četiri stupnja, a ne dihotomne ljestvice

- ima originalno četiri razine problema povezanih s kockanjem

- kratak je, koncizan i zadržava pozornost ispitanika

- zadržava visoku valjanost i pouzdanost u različitim kulturama (Loo, Oei i Raylu, 2011.; So i sur., 2019.).

Originalna klasifikacija razina problematičnog kockanja je na tri razine (isključimo li $0=$ nepostojanje problema). Tako 1-2 boda predstavlja nisku razinu problema, 3-7 bodova umjerenu, a 8 ili više bodova problematično kockanje s negativnim posljedicama i mogućim gubitkom kontrole. $U$ istraživanjima procjene društvenih troškova kockanja uvriježeno je koristiti strože kriterije, kako bi istraživači bili sigurni da u najvišoj razini koriste prevalencijske podatke »sigurnih « patoloških kockara (ovisnika). Tako studije utemeljene na SOGS-u koriste 10+ kriterij za (sigurno) patološko kockanje (Gerstein i sur., 1999.; Macur i sur., 2008.), dok 5-9 bodova predstavlja problematično kockanje, pojmovno nešto nižu razinu problema od patološkog. Prema originalnoj klasifikaciji, u SOGS-u 5+ bodovi već predstavljaju kriterij za vjerojatno patološko kockanje. Za potrebe ovog istraživanja, predvidjeli smo originalnu i strožu/konzervativniju kategorizaciju visoko-problematičnog kockanja prema PGSI-u, na način da smo zadržali i originalni prag (8+) za najproblematičniju razinu, ali smo ga u strožoj kategorizaciji podigli na $12+$ bodova. U Tablici 1. prikazana je originalna kategorizacija i klasifikacija prema istraživanju Glavak Tkalić, Miletić i Sučić (2017.) za uzorku ispitanika od 15 do 64 godina života, te originalna i stroža klasifikacija na uzorku odraslih osoba, koja će se koristiti kao prevalencijski okvir u ovom istraživanju. Što se terminološkog okvira tiče, ranije je navedeno kako posljednjih tridesetak godina postoji izrazito neujednačena terminologija u ovom području. Autori ovo rada odabrali su koristiti suvremenu terminologiju temeljem službenih DSM-5 kriterija, ali vjerojatno i očekivanog prijevoda MKB-11 klasifikacije bolesti. Stoga će se najviša razina problema vezanih u kockanje zvati »ovisnost o kockanju«, što je u skladu i s drugom recentnom terminologijom u području adiktologije, a niža razina "problematično kockanje«. Iz rezultata prikazanih u Tablici 1. prevalencija ovisnosti o kockanju na uzorku odraslih hrvatskih građana iznosi 2,3\% (prema originalnoj klasifikaciji), odnosno 1,1\% (prema strožoj/konzervativnijoj klasifikaciji). 
Tablica 1. Prevalencija ovisnosti o kockanju u Hrvatskoj (PGSI), prema podacima Glavak Tkalić, Miletić i Sučić (2017.), korespondenciji s Glavak Tkalić, te strožoj/konzervativnijoj klasifikaciji autora ovog rada

\begin{tabular}{|c|c|c|c|c|c|}
\hline \multicolumn{2}{|c|}{$\begin{array}{c}\text { PGSI } \\
15 \text { do } 65 \text { godina života } \\
\text { (originalna kategorizacija) }\end{array}$} & \multicolumn{2}{|c|}{$\begin{array}{c}\text { PGSI } \\
18 \text { do } 65 \text { godina života } \\
\text { (originalna kategorizacija) }\end{array}$} & \multicolumn{2}{|c|}{$\begin{array}{c}\text { PGSI } \\
18 \text { do } 65 \text { godina života } \\
\text { (stroža kategorizacija) }\end{array}$} \\
\hline Razine & $\%$ & Razine & $\%$ & Razine & $\%$ \\
\hline Niska razina problema & 4,3 & Niska razina problema & 4,3 & $\begin{array}{c}1-2 \\
\text { Niska razina problema }\end{array}$ & 4,3 \\
\hline $\begin{array}{c}\text { 3-7 } \\
\text { Umjerena razina } \\
\text { problema } \\
\text { [problematični } \\
\text { kockari] }\end{array}$ & 2,9 & $\begin{array}{c}\text { 3-7 } \\
\text { Umjerena razina } \\
\text { problema } \\
\text { [problematični } \\
\text { kockari] }\end{array}$ & 2,8 & $\begin{array}{c}\text { 3-7 } \\
\text { Umjerena razina } \\
\text { problema } \\
\text { [vjerojatni } \\
\text { problematični } \\
\text { kockari] }\end{array}$ & 2,8 \\
\hline $\begin{array}{c}\text { 8+ } \\
\text { Problematično } \\
\text { kockanje s negativnim } \\
\text { posljedicama i } \\
\text { mogućim gubitkom } \\
\text { kontrole } \\
\text { [ovisnici o kockanju] }\end{array}$ & 2,2 & $\begin{array}{c}\mathbf{8 +} \\
\text { Problematično } \\
\text { kockanje s negativnim } \\
\text { posljedicama i } \\
\text { mogućim gubitkom } \\
\text { kontrole } \\
\text { [ovisnici o kockanju] }\end{array}$ & 2,3 & $\begin{array}{c}\text { 8- } 11 \\
\text { Visoka razina } \\
\text { problema } \\
\text { [problematični } \\
\text { kockari] }\end{array}$ & 1,2 \\
\hline & & & & $\begin{array}{c}\text { 12+ } \\
\text { Izrazito visoka razina } \\
\text { problema } \\
\text { [ovisnici o kockanju] }\end{array}$ & 1,1 \\
\hline
\end{tabular}

U odnosu na ukupne prihode od igara na sreću u Republici Hrvatskoj, a temeljem svih poreza, te godišnjih i mjesečnih naknada za priređivanje igara na sreću, posljednjih 5 godina oni iznose preko milijardu kuna, točnije 1,478 milijardi kuna u 2019. godini (Tablica 2.). 
Tablica 2. Prihodi državnog proračuna od igara na sreću (u milijunima HRK), prema službenim podacima Ministarstva financija dobivenih pisanim dopisom 4.6.2020. godine

\begin{tabular}{|c|c|c|c|c|}
\hline & $\begin{array}{c}\text { Porezi i } \\
\text { naknade od } \\
\text { igara na sreću i } \\
\text { zabavnih igara }\end{array}$ & $\begin{array}{c}\text { Porez na } \\
\text { dobitke od } \\
\text { igara na sreću i } \\
\text { ostali porezi od } \\
\text { igara na sreću }\end{array}$ & $\begin{array}{c}\text { Naknade za } \\
\text { priređivanje } \\
\text { igara na sreću }\end{array}$ & UKUPNO \\
\hline 2003. & 190,3 & - & - & 190,3 \\
\hline 2004. & 253,0 & - & - & 253,0 \\
\hline 2005. & 319,6 & - & - & 319,6 \\
\hline 2006. & 431,5 & - & - & 431,5 \\
\hline 2007. & 505,1 & - & - & 505,1 \\
\hline 2008. & 588,6 & - & - & 588,6 \\
\hline 2009. & 532,8 & - & - & 532,8 \\
\hline 2010. & 671,6 & - & - & 671,6 \\
\hline 2011. & - & 31,0 & 635,4 & 666,4 \\
\hline 2012. & - & 30,4 & 675,4 & 705,8 \\
\hline 2013. & - & 28,1 & 741,7 & 769,8 \\
\hline 2014. & - & 117,4 & 728,2 & 845,7 \\
\hline 2015. & - & 305,3 & 740,7 & $1.046,0$ \\
\hline 2016. & - & 326,7 & 801,6 & $1.128,3$ \\
\hline 2017. & - & 339,9 & 890,4 & $1.230,3$ \\
\hline 2018. & - & 349,8 & 970,7 & $1.320,5$ \\
\hline 2019. & - & 373,9 & $1.104,2$ & $1.478,2$ \\
\hline
\end{tabular}

Napomena: Od 2011. godini primjenjuje se novi računski plan prema kojem se konto »Porezi i naknade od igara na sreću i zabavnih igara« dijeli na dva nova konta: »Porez na dobitke od igara na sreću i ostali porezi od igara na sreću« i »Naknade za priređivanje igara na sreću«.

Odgovarajući način za klasificiranje i mjerenje društvenih i ekonomskih troškova ovisnosti o kockanju je vrlo važno metodološko pitanje. Pritom, u postojećoj literaturi autori poput Collins i Lapsley (2003.), Walker i Barnett (1997.), naglašavaju kako je i dalje otvoreno pitanje što treba uključiti i isključiti iz takvih istraživanja. U tekstu koji slijedi prikazani su detalji o dvama metodološkim pristupima mjerenju društvenih $\mathrm{i}$ ekonomskih troškova ovisnosti o kockanju korištenih u ovom istraživanju. 


\section{NORC metodologija}

NORC metodologija jedna je od globalno referentnih, polaznih točaka u mjerenju društvenih i ekonomskih troškova ovisnosti o kockanju. Ona se temelji na opsežnoj anketi na reprezentativnom uzorku ispitanika provedenoj kako bi se istražili različiti oblici posljedica problematičnog kockanja i ovisnosti o kockanju. Podaci dobiveni anketom input su za ekonometrijski model multivarijatne logističke regresije. U model se uključuje više kontrolnih varijabli koje predstavljaju standardan skup obilježja koje su prediktori ponašanja i ishoda povezanih s problematičnim kockanjem i ovisnosti o kockanju. Riječ je o dobi, spolu, etničkoj pripadnosti, stupnju obrazovanja, sklonosti konzumiranja alkohola i droga, regionalna pripadnost, kao i živi li ispitanik u kućanstvu s djecom ili ne. Potrebno je kontrolirati za ova obilježja kako bi se obuhvatile sistemske i idiosinkratske razlike između različitih tipova kockara, a koje bi mogle biti povezane s ishodima koji su predmet ove analize (Gerstein i sur., 1999.).

Rezultat logističkih regresija su procjene stope vjerojatnosti nastanka troškovnih posljedica za problematične kockare/ovisnike o kockanju u odnosu na očekivane stope za pojedince sličnih obilježja, ali koji pripadaju u kategoriju nisko-rizičnih kockara (društvenih kockara, op. autora), tj. pojedinaca koji su kockali ili kockaju, ali nisu razvili značajnije simptome problematičnog kockanja. Time dobivamo procjenu u kojoj mjeri razine problematičnog kockanja povećavaju vjerojatnost nastanka negativnih posljedica poput gubitka posla, prekomjerne zaduženosti, bavljenja kriminalnim aktivnostima, zdravstvenih problema, razvoda braka i sl.

U sljedećem koraku, svakoj od navedenih posljedica procjenjuje se financijski trošak (monetarni efekt) kako bi se procijenio ukupan društveni trošak ovisnosti o kockanju u zemlji. Pritom NORC metodologija striktno razlikuje osobne od društvenih troškova. Drugim riječima, troškovi ovisnosti o kockanju koji opterećuju isključivo kockara, a ne prenose se na članove njegove obitelji, okolinu, društvo ili državu u cjelini, nisu uključeni u društvene troškove prema ovoj metodologiji (Pahor i Cvelbar, 2006.). Po tome se NORC metodologija značajno razlikuje od APC metodologije. S druge strane, NORC metodologija uključuje socijalne transfere (npr. socijalne naknade) koji predstavljaju trošak za porezne obveznike, ali i prihod za primatelja potpore. Valja napomenuti da troškovi koji proizlaze iz problematičnog kockanja i kockanja ovisnika nisu jedini društveni troškovi koji su rezultat kockanja kao takvog, no čine njihov najznačajniji dio (Macur i sur., 2008.).

Kod svih analiziranih troškova učestalost njihova nastanka veća je kod problematičnih kockara i ovisnika, u odnosu na niskorizične kockare ili osobe koje ne kockaju. Troškovi se procjenjuju samo u slučaju da je prethodno navedena razlika u njihovoj učestalosti statistički značajna, s p-vrijednošću manjom od 0,10 za jednosmjerni (eng. one-tailed) test. Iz ovih razlika proizlazi da problematični kockari i ovisnici u prosjeku 
imaju veću vjerojatnost posjedovanja obilježja koja su povezana s nastankom negativnih posljedica, čak i u slučaju da nemaju problema s kockanjem. Primjerice, osobe koje su dijagnosticirane kao problematični kockari/ovisnici imaju veću vjerojatnost razvijanja ovisnosti o alkoholu i drogama te niži stupanj obrazovanja. Ukoliko ne bismo kontrolirali za ovu činjenicu, procjene troškova ovisnosti o kockanju bile bi nerealno visoke, budući da navedena obilježja (ovisnost o alkoholu ili nisko obrazovanje) statistički značajno koreliraju s vjerojatnošću razvoda braka, lošim zdravljem i uključenosti u kriminalne aktivnosti.

Tablica 3. donosi omjere učestalosti pojave različitih posljedica kockanja u odnosu na niskorizične kockare, procijenjene multivarijatnim logističkim regresijama. Vrijednost 2,29 kod kategorije "razvod braka« kod ovisnika o kockanju možemo interpretirati na način da je vjerojatnost razvoda braka 2,29 puta veća kod ovisnika u odnosu na niskorizične kockare (društvene kockare), nakon što kontroliramo za sva ostala obilježja koja bi mogla utjecati na nastanak razvoda braka.

Tablica 3. Usporedba učestalosti pojava posljedica/problema između ovisnika o kockanju (patoloških kockara), problematičnih i niskorizičnih kockara (prema Gerstein i sur., 1999.: 58)

\section{Vrsta posljedice/problema}

\section{Omjer učestalosti pojave}

u odnosu na nisko-rizične kockare

[tzv. društvene kockare]

\section{Problematični kockari}

Gubitak posla

Osobni bankrot

Razvod braka

Loše ili osrednje zdravlje

Liječenje mentalnih bolesti

Uhićenje

Zatvorska kazna

\section{Ovisnici o kockanju (patološki kockari)}

Gubitak posla

Osobni bankrot

Razvod braka

Loše ili osrednje zdravlje

Liječenje mentalnih bolesti

Uhićenje 


\section{APC metodologija}

Druga najčešće korištena metodologija procjene društvenih i ekonomskih troškova ovisnosti o kockanju razvijena je od strane Australske komisije za produktivnost (eng. The Australian Productivity Commission - APC). Riječ je o glavnom vladinom revizijskom i savjetodavnom tijelu koje izrađuje neovisne analize i mišljenja o mikroekonomskoj politici, regulaciji i nizu drugih socijalnih i okolišnih pitanja s ciljem maksimiziranja društvenih koristi. U skladu s navedenim, APC je pripremio istraživanje s ciljem formuliranja prijedloga za djelovanje u području igara na sreću (Productivity Commission, 1999.).

Kao i kod prethodno objašnjene NORC metodologije, i APC metodologija temelji se na Nacionalnom anketnom istraživanju koje adresira ponašanja i ishode povezane s problematičnim kockanjem i ovisnosti o kockanju. Riječ je o opsežnom istraživanju koje prodire u dublje metodološke i podatkovne aspekte procjene pojedinih kategorija troškova. Međutim, dok se NORC metodologija više oslanja na regresije i kvantitativna istraživanja, APC metodologija je i longitudinalno, kvalitativno istraživanje koje se temelji na pristupu samoprocjene (eng. self-assessment approach). Kvantitativni pristup kod APC metodologije temelji se na općoj učestalosti određenih društvenih troškova (primjerice, bankrot, kriminal, samoubojstvo) bilo tijekom vremena ili u regiji, na temelju čega se utvrđuje postoji li veza s intenzitetom kockanja.

APC metodologija također uzima u obzir kauzalnost u svojim procjenama utjecaja problematičnog kockanja. Drugim riječima, obilježja poput ovisnosti o alkoholu u prosjeku pridonose razvoju zdravstvenih problema, uključenosti u kriminalne aktivnosti i slično, čak i onda kada se izolira problem s kockanjem. Stoga, APC metodologija kod procjene troškova prilagođava utjecaj problematičnog kockanja na način da umanji za $20 \%$ broj ljudi za koje se procjenjuje da su pogođeni, budući da je za niz štetnih posljedica, posebno depresiju i razvod, razumno pretpostaviti da će određeni postotak osoba imati problema, čak i ako ne budu kockali (Productivity Commission, 1999.). Ipak, tamo gdje su štetne posljedice bile izravnije financijske, primjerice, pronevjera ili bankrot, APC metodologija sagledava kockanje uglavnom kao glavni i najvažniji problem, jer su izravne negativne posljedice kockanja problemi vezani uz financijske poteškoće.

Ovaj nalaz u skladu je s nalazima NORC metodologije da kockari koji su se bavili kriminalom uglavnom nisu imali prethodnu povijest kriminalnih aktivnosti. Unatoč razlikama u metodologiji i varijacijama u načinu postavljanja pitanja, gdje se može usporediti, stope prevalencije generirane u NORC studiji ovisnika o kockanju slične su onima iz APC studije (Tablica 4.) (Gerstein i sur., 1999.). 
Tablica 4. Usporedba stope prevalencije (odabrane posljedice) prema NORC i APC istraživanjima (prema Productivity Commission, 1999., Appendix J6: 204)

\begin{tabular}{lcc}
\hline & NORC & APC \\
& $\%$ & $\%$ \\
\hline Gubitak posla & 8 (posljednjih 12 mjeseci) & 18,1 (ikad) \\
Osobni bankrot (ikad) & 8,4 & 8,3 \\
Razvod braka (ikad) & 20,1 & 23,4 \\
Uhićenje (ikad) & 13 & 17 \\
Zatvorska kazna (ikad) & 15 & 6,9 \\
\hline
\end{tabular}

Nadalje, APC metodologijom pretpostavlja se da većinu ekonomskih i društvenih troškova snose problematični kockari i ovisnici o kockanju. lako postoji niz definicija problematičnih kockara, kao i dijagnostičkih instrumenata, te skala za mjerenje prevalencije, zajedničko obilježje navedene skupine ogleda se kroz dva aspekta koja uvažava i APC metodologija: (1) gubitak kontrole nad vlastitim ponašanjem, (2) prisutnost negativnih osobnih, ekonomskih i socijalnih efekata koji su posljedica kockanja. Važno je naglasiti da se izračunavanje nekih aspekata troškova veže i za sve redovne (društvene) igrače, a ne samo za problematične i ovisnike. Prema rezultatima Nacionalne ankete o igrama na sreću u Australiji, koja je obuhvatila sve redovite društvene kockare/igrače (oni koji u prosjeku igraju posebne igre na sreću najmanje jednom tjednom), skupinu problematičnih kockara i ovisnika o kockanju čini 15\% svih redovitih igrača (Macur i sur., 2008.).

APC metodologija razlikuje unutarnje i vanjske troškove te transfere. Vanjski troškovi su oni koje drugima nameće kockar, a da pritom pogođeni nemaju utjecaja na iste. Takvi troškovi obično služe kao podloga za intervenciju nositelja ekonomskih politika. Međutim, APC metodologija uvažava i druge vrste troškova, tj. unutarnje troškove kockara (pored novca koji se troši izravno na kockanje), a koje kockar nameće zajednici. Riječ je o neopipljivim, nematerijalnim (eng. intangible) troškovima. Upravo uključivanje unutarnjih troškova predstavlja glavnu razliku između NORC i APC metodologije. Važnost uključivanja unutarnjih troškova u ukupne ekonomske i društvene troškove opravdana je zbog sumnje u kojoj su mjeri kockari uopće svjesni stvarnih troškova i koristi kockanja, posebno s aspekta zablude o načinu funkcioniranja igara i istinske vjerojatnosti pobjede. Ovdje se metodološki nameće pitanje koliko su problematični kockari i ovisnici uopće »dobrovoljni« potrošači. APC metodologija ističe isključivanje nematerijalnih troškova kao najvažniji čimbenik očigledno niskih procijenjenih društvenih troškova problema kockanja. Oni, naime, mogu biti veliki kao, ili puno veći od, izravnih financijskih troškova koje se nameću društvu uslijed problema s kockanjem. 
Dakle, nematerijalni troškovi su podjednako stvarni koliko i materijalni, ali zato što ne postoji tržišni mehanizam koji bi signalizirao vrijednosti koje bi ljudi postavili na te troškove, teže ih je izmjeriti. Ono što APC cilja jest utvrditi koliko su problematični kockari različitih razina rizičnosti doista (ne)sposobni donijeti vlastite odluke o potrošnji, barem dijela koji se odnosi na kockanje, što pritom generira znatne troškove i njima i društvu u cjelini. Kao važan nalaz ovakvog pristupa proizlazi da bi takve kockare trebalo bolje educirati kako bi mogli vrednovati stvarne troškove i koristi kockanja, te ih treba ograničiti od povređivanja sebe i svoje okoline posredstvom kockanja.

Posljednja vrsta troškova su transferni troškovi. Troškovi transfera, prema kriteriju alokativne efikasnosti, ne pripadaju društvenim troškovima, jer je riječ o transferima društva koji ne doprinose smanjenju društvenog blagostanja (Walker i Barnett, 1997.). Međutim, APC metodologija naglašava da, iako transferi ne predstavljaju neto trošak za društvo, oni su i dalje relevantni za onoga koji ih plaća. Ako su transferi veliki, vrijedno je istražiti isplative načine kako ih umanjiti ili ako su dio države blagostanja, načine kako da budu učinkovitijima (Productivity Commission, 1999.). U protivnom se ne trebaju uključiti u ukupne ekonomske i društvene troškove.

U konačnici, APC metodologija obuhvaća pet kategorija društvenih i ekonomskih troškova: financijski troškovi, troškovi vezani uz produktivnost i zaposlenost, troškovi kriminala, osobni i obiteljski troškovi te troškovi liječenja ovisnosti. Pritom financijski troškovi obuhvaćaju bankrot i dugove, a produktivnost i zaposlenost se mjere kroz pad produktivnosti na radnom mjestu i troškove proizašle iz promjena radnog mjesta. Troškovi kriminala uključuju troškove policijske intervencije, sudske troškove i troškove zatvora. Među osobne i obiteljske troškove spadaju emocionalna bol bližnjih, financijski i emotivni troškovi razvoda, prekinute veze, nasilja, depresije, samoubojstva i pokušaja samoubojstva.

\section{REZULTATI I RASPRAVA}

Prilikom izračuna ukupnih ekonomskih i društvenih troškova, prema NORC i APC metodologiji, u ovom istraživanju pratio se pristup Jakliča i sur. (2006.) te Macur i sur. (2008.) koji su primijenili navedene dvije metodologije prilikom analiziranja društvenih troškova kockanja u Sloveniji. S obzirom na njihovu sveobuhvatnost, NORC i APC metodologija primjenjive su u velikoj mjeri i pri procjeni društvenih i ekonomskih troškova kockanja u Hrvatskoj, uvažavajući pritom socio-demografske specifičnosti društva i okruženja koje se analizira. Primijeniti navedene metodologije na hrvatskom primjeru ne znači mehanički prenositi troškovne specifikacije iz američkog ili australskog u hrvatski kontekst. 
Sukladno sličnim studijama koje su u Sloveniji proveli ranije navedeni autori, pretpostavljamo da su ključna relativna obilježja problematičnih kockara i ovisnika o kockanju u Hrvatskoj, u odnosu na ostatak hrvatske populacije, približno slična njihovim relativnim obilježjima u SAD-u u odnosu na ostatak američke populacije, odnosno u Australiji. Zbog toga smatramo da su rezultati logističkih regresija provedenih u američkom slučaju koji procjenjuju omjere učestalosti nastanka negativnih posljedica kockanja za problematične kockare i ovisnike, u odnosu na niskorizične (društvene) kockare, primjenjivi i na hrvatski kontekst. Pritom uvažavamo činjenicu da je financijski obujam društvenih troškova kockanja u Hrvatskoj vrlo različit od onih u SAD-u i Australiji, stoga se taj dio zasebno procijenio u ovoj studiji. Ipak, ankete provedene u Sjedinjenim Američkim Državama i Australiji, na kojima se temelje navedene dvije metodologije, nisu raspoložive u Hrvatskoj, stoga se naša analiza nužno mora temeljiti na određenim pretpostavkama. Budući da APC metodologija uzima u obzir neke troškove koji nisu obuhvaćeni NORC metodologijom, a izostavlja druge, te dvije metodologije nisu preslikavanje. APC metodologiju u ovom kontekstu uzimamo kao provjeru robusnosti rezultata kod procjene ukupnih ekonomskih i društvenih troškova ovisnosti o kockanju. Pritom se mogu očekivati niži troškovi dobiveni APC metodologijom u odnosu na NORC, budući da je APC ocjenjena kao konzervativnija metoda (Productivity Commission, 1999.).

U Tablici 5. i na Slici 2. ponuđen je sumarni prikaz ekonomskih i društvenih troškova po problematičnom i ovisniku o kockanju koristeći NORC metodologiju. Ukupni godišnji trošak po problematičnom kockaru iznosi 6 554,64 kune, od čega najveći udio (78\%) čine troškovi povezani s tržištem rada. S druge strane, ukupni godišnji trošak po ovisniku o kockanju iznosi 11 379,75 kuna. lako su i kod ove kategorije kockara najznačajniji troškovi povezani s tržištem rada, osjetan udio u ukupnoj strukturi imaju i zdravstveni te financijski troškovi. Detaljnija razrada izračuna ekonomskih i društvenih troškova po stavkama zbog svoje opsežnosti nije mogla biti uključena u ovaj rad, ali svi izračuni dostupni su na zahtjev kod autora. 
Tablica 5. Godišnji ekonomski i društveni troškovi po problematičnom i ovisniku o kockanju prema NORC metodologiji

\begin{tabular}{|c|c|c|}
\hline Vrsta troška & $\begin{array}{l}\text { Problematični } \\
\text { kockar }\end{array}$ & $\begin{array}{l}\text { Ovisnik o } \\
\text { kockanju }\end{array}$ \\
\hline a. Troškovi povezani s tržištem rada & 5110,75 kn & 7737,78 kn \\
\hline - gubitak posla kao trošak za poslodavca & 1213,48 kn & $1837,24 \mathrm{kn}$ \\
\hline - sudski troškovi zbog gubitka posla & $4,19 \mathrm{kn}$ & $6,35 \mathrm{kn}$ \\
\hline - trošak naknade za nezaposlene & $3824,60 \mathrm{kn}$ & $5790,51 \mathrm{kn}$ \\
\hline - trošak socijalnih naknada & $68,48 \mathrm{kn}$ & $103,68 \mathrm{kn}$ \\
\hline b. Financijski troškovi & 791,87 kn & $1622,58 \mathrm{kn}$ \\
\hline c. Trošak kriminala & 188,77 kn & 339,48 kn \\
\hline • troškovi uhićenja & $111,20 \mathrm{kn}$ & $143,81 \mathrm{kn}$ \\
\hline - troškovi izdržavanja zatvorske kazne & $77,57 \mathrm{kn}$ & 195,67 kn \\
\hline d. Obiteljski troškovi & $5,92 \mathrm{kn}$ & $20,10 \mathrm{kn}$ \\
\hline e. Zdravstveni troškovi & $457,33 \mathrm{kn}$ & $1659,81 \mathrm{kn}$ \\
\hline - troškovi fizičkog liječenja & $159,50 \mathrm{kn}$ & $1.097,36 \mathrm{kn}$ \\
\hline - troškovi psihičkog liječenja & $297,83 \mathrm{kn}$ & $226,92 \mathrm{kn}$ \\
\hline • troškovi terapija & - & $335,53 \mathrm{kn}$ \\
\hline $\begin{array}{l}\text { UKUPNI GODIŠNJI TROŠAK PO IGRAČU } \\
(a+b+c+d+e)\end{array}$ & 6554,64 kn & $11379,75 \mathrm{kn}$ \\
\hline
\end{tabular}

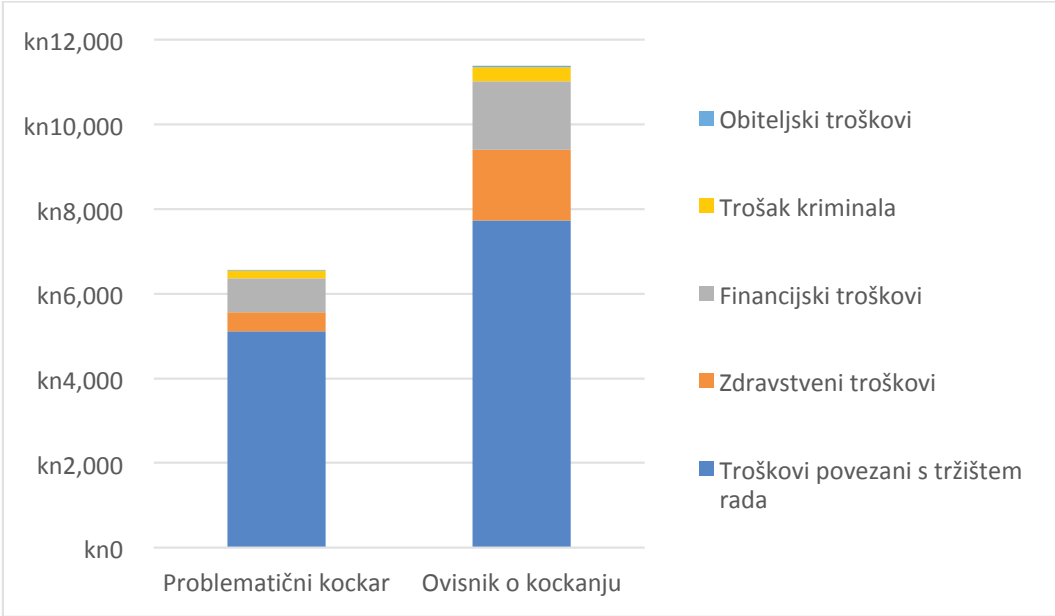

Slika 2. Prikaz procijenjenih godišnjih ekonomskih i društvenih troškova po problematičnom kockaru i ovisniku o kockanju prema NORC metodologiji 
Prema posljednje dostupnim podacima Državnog zavoda za statistiku (2019.), u Hrvatskoj je u 2018. godini živjelo 2544.675 osoba u dobi između 18 i 64 godine. Prema podacima proizašlih iz istraživanja istraživača Instituta društvenih znanosti Ivo Pilar (Glavak Tkalić, Miletić i Sučić, 2017.), udio problematičnih kockara prema strožem kriteriju prevalencije ovisnosti (PGSI 8-11) iznosi 1,2\% ukupne populacije od 18 do 64 godine u $\mathrm{RH}$, dok po originalnom kriteriju (PGSI 3-7) taj udio iznosi 2,8\%. S druge strane, udio osoba ovisnih o kockanju prema strožem kriteriju prevalencije ovisnosti (PGSI 12+) iznosi 1,1\% ukupne populacije od 18 do 64 godine, dok po originalnom kriteriju (PGSI 8+) taj udio iznosi 2,3\%.

Tablica 6. donosi izračun ukupnih godišnjih ekonomskih i društvenih troškova kockanja u Hrvatskoj prema NORC metodologiji. Prema našim procjenama, ukupan godišnji ekonomski i društveni trošak kockanja u Hrvatskoj iznosi oko 519 milijuna kuna prema strožem kriteriju prevalencije ovisnosti, odnosno 1,1 milijardi kuna prema originalnom kriteriju prevalencije ovisnosti.

Tablica 6. Ukupni godišnji ekonomski i društveni troškovi kockanja u Hrvatskoj prema NORC metodologiji

\begin{tabular}{lccccc}
\hline & $\begin{array}{c}\text { Udio } \\
\text { problematičnih }\end{array}$ & $\begin{array}{c}\text { Trošak } \\
\text { problematičnih }\end{array}$ & $\begin{array}{c}\text { Udio } \\
\text { ovisnika }\end{array}$ & $\begin{array}{c}\text { Trošak } \\
\text { ovisnika }\end{array}$ & UKUPNO \\
\hline $\begin{array}{l}\text { Stroži kriterij } \\
\text { prevalencije }\end{array}$ & $1,2 \%$ & $200153143 \mathrm{kn}$ & $1,1 \%$ & $318535419 \mathrm{kn}$ & $518688561 \mathrm{kn}$ \\
\hline $\begin{array}{l}\text { Originalni } \\
\text { kriterij } \\
\text { prevalencije }\end{array}$ & $2,8 \%$ & $467023999 \mathrm{kn}$ & $2,3 \%$ & $666028603 \mathrm{kn}$ & $1133052602 \mathrm{kn}$ \\
\hline
\end{tabular}

Prihodi državnog proračuna Republike Hrvatske od poreza na dobitke i ostalih poreza od igara na sreću te naknada za priređivanje igara na sreću u 2019. godini iznosili su približno 1,5 milijardi kuna (Ministarstvo financija, 2020.). Stavimo li procijenjene ekonomske i društvene troškove kockanja u kontekst prihoda državnog proračuna od istih aktivnosti, prema našim izračunima, troškovi kockanja prema NORC metodologiji iznose između 35\% i 77\% godišnjih prihoda proračuna od kockanja i igara na sreću.

U Tablici 7. i na Slici 3. ponuđen je sumarni prikaz ekonomskih i društvenih troškova po problematičnom kockaru i ovisniku o kockanju koristeći APC metodologiju. Ukupni godišnji trošak po problematičnom kockaru iznosi 6 788,2 kune, od čega najveći udio $(71,5 \%)$ čine troškovi vezani uz produktivnost i zaposlenost. S druge strane, ukupni godišnji trošak po ovisniku o kockanju iznosi 10 702,8 kuna. I kod ove kategorije kockara najznačajniji troškovi vezani su uz produktivnost i zaposlenost $(68,9 \%)$. 
Tablica 7. Godišnji ekonomski i društveni troškovi po problematičnom kockaru i ovisniku o kockanju prema APC metodologiji

\begin{tabular}{|c|c|c|}
\hline Vrsta troška & $\begin{array}{l}\text { Problematični } \\
\text { kockar }\end{array}$ & $\begin{array}{l}\text { Ovisnik o } \\
\text { kockanju }\end{array}$ \\
\hline a. Troškovi vezani uz produktivnost i zaposlenost & $4852,2 \mathrm{kn}$ & 7371,9 kn \\
\hline - pad produktivnosti & $58,9 \mathrm{kn}$ & $114,7 \mathrm{kn}$ \\
\hline - troškovi države / naknade za nezaposlene & $3.633,4 \mathrm{kn}$ & $5.501,0 \mathrm{kn}$ \\
\hline - troškovi države / socijalne naknade & $3,4 \mathrm{kn}$ & $5,2 \mathrm{kn}$ \\
\hline - troškovi poslodavca & $1.156,5 \mathrm{kn}$ & $1.751,0 \mathrm{kn}$ \\
\hline b. Financijski troškovi & $963,1 \mathrm{kn}$ & $1.379,9 \mathrm{kn}$ \\
\hline c. Trošak kriminala & $188,8 \mathrm{kn}$ & 339,5 kn \\
\hline - trošak zatvora & $74,2 \mathrm{kn}$ & $188,9 \mathrm{kn}$ \\
\hline - trošak policijske intervencije & $106,4 \mathrm{kn}$ & $138,8 \mathrm{kn}$ \\
\hline - sudski troškovi & $3,6 \mathrm{kn}$ & $1,4 \mathrm{kn}$ \\
\hline d. Osobni i obiteljski troškovi & $465,7 \mathrm{kn}$ & 815,2 kn \\
\hline - emocionalna bol za članove obitelji & $442,3 \mathrm{kn}$ & $724,1 \mathrm{kn}$ \\
\hline - financijski i emocionalni troškovi razvoda & $15,0 \mathrm{kn}$ & $13,8 \mathrm{kn}$ \\
\hline - emocionalni troškovi prekida veze & $6,9 \mathrm{kn}$ & $6,3 \mathrm{kn}$ \\
\hline - trošak nasilja & - & $7,7 \mathrm{kn}$ \\
\hline - trošak depresije & $1,5 \mathrm{kn}$ & $1,4 \mathrm{kn}$ \\
\hline - razmišljanje o samoubojstvu & - & $21,6 \mathrm{kn}$ \\
\hline - pokušaj samoubojstva & - & $15,9 \mathrm{kn}$ \\
\hline $\begin{array}{l}\text { - učinak pokušaja samoubojstva na članove } \\
\text { obitelji }\end{array}$ & - & $24,4 \mathrm{kn}$ \\
\hline e. Troškovi liječenja ovisnosti & $318,5 \mathrm{kn}$ & 796,4 kn \\
\hline $\begin{array}{l}\text { UKUPNI GODIŠNJI TROŠAK PO IGRAČU }(a+b+c \\
+d+e)\end{array}$ & $6788,2 \mathrm{kn}$ & $10702,8 \mathrm{kn}$ \\
\hline
\end{tabular}




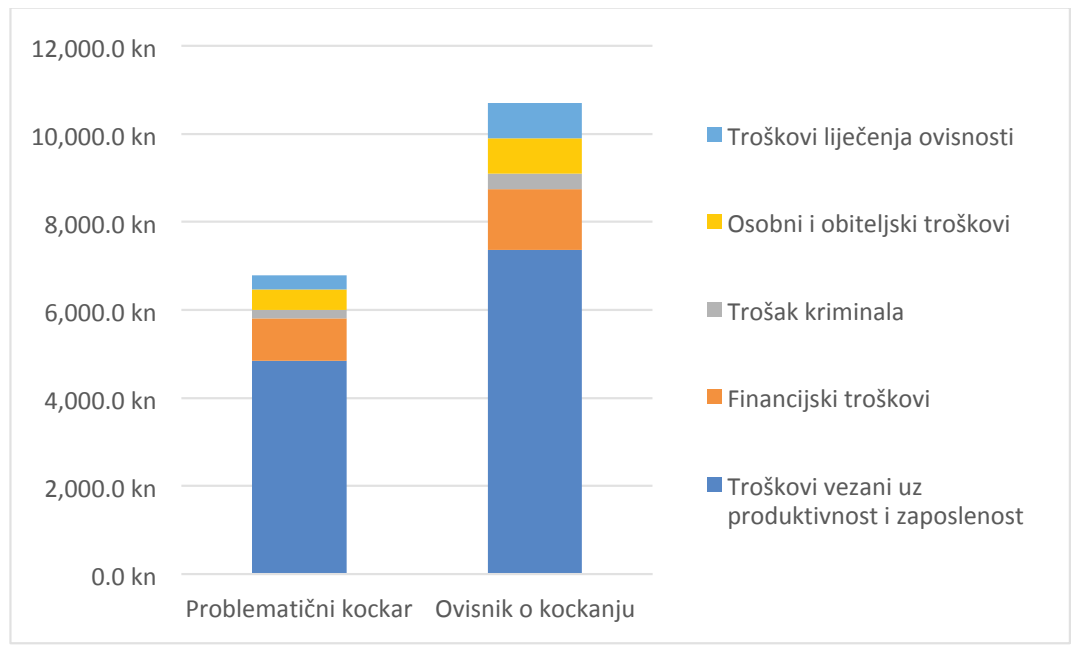

Slika 3. Prikaz procijenjenih godišnjih ekonomskih i društvenih troškova po problematičnom kockaru i ovisniku o kockanju prema APC metodologiji

Na temelju istih podataka koji su se koristili kod izračuna ukupnih troškova prema NORC metodologiji, u Tablici 8. prikazan je izračun ukupnih godišnjih ekonomskih i društvenih troškova kockanja u Hrvatskoj prema APC metodologiji. Prema našim procjenama, ukupan godišnji ekonomski i društveni trošak kockanja u Hrvatskoj iznosi oko 506 milijuna kuna prema strožem kriteriju prevalencije ovisnosti, odnosno 1,1 milijardi kuna prema originalnom kriteriju prevalencije ovisnosti. Navedeni troškovi su manji kod procjene temeljem APC metodologije za 11815053 kn prema strožem kriteriju prevalencije ovisnosti, odnosno za 22975082 kn prema originalnom kriteriju prevalencije ovisnosti u odnosu na procjene temeljem NORC metodologije.

Tablica 8. Ukupni godišnji ekonomski i društveni troškovi kockanja u Hrvatskoj prema APC metodologiji

\begin{tabular}{|c|c|c|c|c|c|}
\hline & $\begin{array}{c}\text { Udio } \\
\text { problematičnih }\end{array}$ & $\begin{array}{c}\text { Trošak } \\
\text { problematičnih }\end{array}$ & $\begin{array}{c}\text { Udio } \\
\text { ovisnika }\end{array}$ & $\begin{array}{c}\text { Trošak } \\
\text { ovisnika }\end{array}$ & UKUPNO \\
\hline $\begin{array}{l}\text { Stroži kriterij } \\
\text { prevalencije }\end{array}$ & $1,20 \%$ & 207285765 kn & $1,10 \%$ & 299587743 kn & 506873508 kn \\
\hline $\begin{array}{l}\text { Originalni } \\
\text { kriterij } \\
\text { prevalencije }\end{array}$ & $2,80 \%$ & 483666784 kn & $2,30 \%$ & 626410736 kn & 1110077520 kn \\
\hline
\end{tabular}

Kao što je prethodno naglašeno, prihodi državnog proračuna Republike Hrvatske od poreza na dobitke i ostalih poreza od igara na sreću te naknada za priređivanje igara 
na sreću u 2019. godini iznosili su približno 1,5 milijarde kuna. Stavimo li procijenjene ekonomske i društvene troškove kockanja u kontekst prihoda državnog proračuna od istih aktivnosti, prema našim izračunima, troškovi kockanja prema APC metodologiji iznose između 34\% i 74\% godišnjih prihoda proračuna od kockanja i igara na sreću, što se ne razlikuje značajno od procjena dobivenih NORC metodologijom.

\section{Istraživačka ograničenja}

Procjena ukupnih ekonomskih i društvenih troškova kockanja predstavlja istraživački izazov. Prije svega, nameće se pitanje koje kategorije troškova spadaju u društvene troškove. Različite metodologije će u konačnici primijeniti i različite kategorije društvenog troška. Zbog postojanja ovakve rasprave, u ovom istraživanju odabrale su se dvije najčešće korištene metode mjerenja troškova ovisnosti o kockanju u svijetu, a koje predstavljaju prekretnicu u ovom području istraživanja (Reith, 2006.).

Nadalje, prilikom izračuna navedenih troškova potrebno je obuhvatiti i teže mjerljive kategorije troškova, poput troškova kriminala, emocionalne boli obitelji, troškova nasilja, pokušaja samoubojstva i troškova depresije. Neopipljivi troškovi mogu se identificirati, ali njihovo mjerenje je otežano budući da takve kategorije troškova nemaju tržišnu cijenu. Prilikom kvantificiranja se u osnovi pripisuje subjektivna vrijednost na okolnost ili događaj.

Primjena dvije relevantne metodologije (NORC i APC) na primjeru Republike Hrvatske predstavlja dodatni izazov. Naime, nameću se određena ograničenja koja proizlaze iz činjenice kako su navedene dvije metodologije temeljene na anketnom istraživanju. Nažalost, takve ankete nisu raspoložive u Hrvatskoj, stoga se kod ovog istraživanja preuzeo dio parametara prateći pristup Jakliča i sur. (2006.), te Macur i sur. (2008.) na području Republike Slovenije.

Ipak, ono što se može zaključiti iz ovakve kvantifikacije, sa svim svojim ograničenjima, je da su društveni i ekonomski troškovi (kao i koristi) od djelatnosti kockanja znatni i svakako nisu zanemarivi. To pokazuje važnost reguliranja uvjeta za pristup kockanju i, posebno, potrebu da se nositelji ekonomske politike usredotoče na mjere koje će minimizirati i spriječiti štete, odnosno koje mogu učinkovito ograničiti troškove zbog kockanja bez značajnog smanjenja koristi za rekreativne igrače. Kako bi procijenjeni troškovi što bolje odražavali stvarnu sliku, potrebno je provesti longitudinalno i multidisciplinarno istraživanje za Republiku Hrvatsku. 


\section{ZAKLJUČAK}

Rezultati ovog istraživanja svakako relativiziraju koristi, odnosno prihode u državni proračun od igara na sreću, te doprinose znanstvenim spoznajama koje upućuju na potrebu implementacije širih politika i obveza odgovornog priređivanja igara na sreću s ciljem smanjivanja društvenih troškova kockanja. Ekonomski aspekti uvijek imaju dvije strane, te je zajedničkim dijalogom moguće napraviti kompromise između financijskih interesa države s jedne strane, priređivača s druge strane, te javnozdravstvenih interesa i potreba građana/igrača. Kao što navode Sulkunen i sur. (2019.: 178): „Ravnotežu između štete uzrokovane kockanjem i dobiti od nje ne bi trebalo tražiti vaganjem benefita i nedostataka kockanja prema društvu u cjelini. Umjesto toga, potrebna je analiza je li kockanje uvijek najbolji način postizanja društvenih benefita i mogu li se nedostaci adresirati bez pojačanog tereta na one koji su ionako pretjerano opterećeni posljedicama.»

U ovom smo radu izračunate društvene troškove kockanja u Republici Hrvatskoj pokušali smjestiti u što je moguće jasniji kontekst. $S$ jedne strane, razumijevanjem ovisnosti o kockanju kao pojave, uz kliničku sliku cijelog spektra štetnih psihosocijalnih posljedica kockanja, a s druge strane ponuditi zaključno okvir mjera i prijedloga za odgovornije priređivanje igara na sreću koje bi valjalo pravno regulirati. Time se može ostvariti i nacionalna ujednačenost u zaštiti građana/igrača, ravnopravnost svih priređivača na tržištu, ali i vrijednosni okvir države koji poštuje znanstveno utemeljene preporuke i evaluirane dobre prakse s ciljem promocije javnog zdravlja u najširem smislu. Ključnu ulogu u visini godišnjih troškova ima stopa ovisnosti, odnosno prevalencija ovisnosti u populaciji.

Ovisnika o kockanju će uvijek biti, ali bi njihov broj trebalo minimalizirati u najvećoj mogućoj mjeri, što je moguće učiniti i temeljem izučavanja modela drugih država čija je prevalencija ovisnosti svedena na minimum. U ovom su području Calado i Griffiths (2016.) napravili, do sada, najopsežniju sistematičnu analizu literature rezultata mnogobrojnih svjetskih studija prevalencije ovisnosti o kockanju od 2000. do 2015. godine. Pažljivim probirom imali su specifične uključujuće i isključujuće kriterije, a cilj je bio obuhvatiti sve prevalencijske studije provedene na nacionalnoj razini, na reprezentativnim uzorcima, pri čemu su one odabirane temeljem dva kriterija: (1) da su objavljene od 2000. godine na više te (2) da nude podatke o prevalencijskim podacima za odrasle problematične i/ili patološke kockare (ovisnike o kockanju). Isključene su studije koje su rađene na specifičnim uzorcima (primjerice, studentima, zatvorenicima, igračima, beskućnicima, ovisnicima o drogama i slično), studije koje su imale manje od 500 sudionika, te one koje nisu koristile standardizirane instrumente procjene ovisnosti o kockanju. Takvim pristupom obuhvatili su 92 
studije sa svih kontinenata, ali najviše iz Europe, Azije, Sjeverne Amerike i Oceanije. Rezultati na pet kontinenata pokazuju varijabilitet problema ovisnosti o kockanju od 0,1 do 5,8\% u odnosu na prošlogodišnju prevalenciju. Uzimajući u obzir cjeloživotnu prevalenciju, varijabilitet rezultata kreće se od 0,7 do 6,5\%. Promatrajući globalno po kontinentima, prošlogodišnja prevalencija problematičnog kockanja u Sjevernoj Americi je u rasponu od 2 do 5\%, u Aziji od 0,5 do 5,8\%, Oceaniji od 0,4 do 0,7\%, a u Europi od 0,1 do 3,4\%. Time zapravo Azija i Europa pokazuju najveći varijabilitet u rezultatima, ali i najniže stope prevalencije. U Europi se od zemalja koje imaju prevalenciju manju od $<1 \%$ ističu Austrija, Francuska, Njemačka, Island, Norveška, Portugal i Velika Britanija. Upravo takvi rezultati pokazuju da regulatorni okvir koji determinira i dostupnost i pristupačnost igara na sreću, ali i odgovornost u njihovom priređivanju, ima utjecaja na prevalenciju ovisnosti o kockanju u populaciji.

Odgovorno priređivanje igara na sreću sastavni je dio društveno odgovorno poslovanja priređivača igara na sreću. Ovaj aspekt specifičan je samo za priređivače igara na sreću, odnosno on je differentia specifica djelatnosti kockanja u odnosu na druge. Stoga bi on trebao biti i sastavni dio kako nacionalnih politika (zakona, pravilnika, nacionalnih standarda, strategija i preporuka), tako i strategija poslovanja svih priređivača pojedinačno.

Formalno se odgovorno priređivanje igara na sreću definira kao skup politika i aktivnosti usmjerenih na (Hing, Russell i Hronis, 2016.):

1. priređivanje igara na sreću u skladu s međunarodnim i nacionalnim pravnim okvirom

2. osiguravanje sigurnog prostornog okruženja, kao i online prostora i transakcija

3. minimaliziranje štetnih psihosocijalnih posljedica priređivanja igara na sreću u društvu.

U najužem smislu, ono je vezano uz osiguravanje maksimalne moguće zaštite igrača od svih realnih i potencijalnih rizika, odnosno štetnih posljedica kockanja (od financijskih do onih psihosocijalnih). Ključne aspekte odgovornog priređivanja igara na sreću moguće je promatrati na pet razina, odnosno kroz pet područja (Ricijaš, 2019.; Ricijaš, Maglica i Dodig Hundrić, 2019.):

1. dostupnost i pristupačnost igara na sreću

2. oglašavanje igara na sreću

3. online sigurnost priređivanja igara na sreću

4. edukacije u području djelatnosti kockanja i ovisnosti o kockanju

5. psihosocijalne intervencije u području kockanja kao rizičnog ponašanja.

U Republici Hrvatskoj su na svim ovim razinama identificirani brojni problemi i rizici, od kojih ćemo ovdje nabrojati samo neke, a koji svi doprinose štetnim posljedicama kockanja i društvenim troškovima koji opterećuju državni proračun i narušavaju zdravlje i dobrobit pojedinaca, obitelji, zajednica i društva. To su: 
- nedovoljno kvalitetno regulirana dostupnost igara na sreću,

- izrazita geovremenska pristupačnost igara na sreću,

- izražena mogućnost pristupa maloljetnika igrama na sreću, usprkos zakonskim zabranama,

- nedovoljno kvalitetno regulirano oglašavanje igara na sreću,

- nepostojanje standarda oglašavanja igara na sreću,

- online priređivanje igara na sreću priređivača koji nisu stekli pravo online priređivanja prema pozitivnim hrvatskim propisima (tzv. ilegalni priređivači),

- nedovoljna i neobavezna edukacija svih relevantnih dionika u ovom području,

- nedostatne psihosocijalne intervencije u području kockanja kao rizičnog ponašanja i ovisnosti o kockanju kao poremećaja mentalnog zdravlja.

Autori ovog rada zalažu se za postavljanje pravnog regulatornog standarda odgovornog priređivanja igara na sreću, kao što je to, primjerice, regulirano u švedskom Zakonu o kockanju (Ministry of Finance - Sweden, 2019. Gambling Act 2018.: 1138) koji sadrži posebno poglavlje vezano uz odgovorno priređivanje (poglavlje 14), kao i ono vezano uz marketing igara na sreću (poglavlje 15). Takav cjelovit pristup smatramo jedinim načinom da se na nacionalnoj razini djeluje prema smanjivanju prevalencije ovisnosti o kockanju u Hrvatskoj, koja naizgled djeluje niskom (1,10\% - 2,30\%), ali koja dokazano stvara značajne društvene i ekonomske troškove te pokazuje drugu stranu medalje prihoda u državni proračun. Smatramo da reguliranje i implementacija odgovornog priređivanja igara na sreću reflektira jasan vrijednosni okvir države prema balansiranju tržišta, minimaliziranju štetnih posljedica i promociji javnog zdravlja za građane jednog društva.

\section{LITERATURA}

1. Arthur, D., Tong, W. L., Chen, C. P., Hing, A. Y., Sagara-Rosemeyer, M., Kua, E. H. \& Ignacio, J. (2008). The validity and reliability of four measures of gambling behavior in a sample of Singapore University students. Journal of Gambling Studies, 24 (4), 451-462. https://doi.org/10.1007/s10899-008-9103-y.

2. Bodor, D. (2018). Usporedba psihosocijalnoga funkcioniranja osoba koje se liječe zbog ovisnosti o kockanju i alkoholu. Doktorska disertacija. Zagreb: Stomatološki fakultet Sveučilišta u Zagrebu.

3. Boughton, R. \& Falenchuk, O. (2007). Vulnerability and comorbidity factors of female problem gambling. Journal of Gambling Studies, 23 (3), 323-334. https:// doi.org/10.1007/s10899-007-9056-6.

4. Browne, M., Hing, N., Rockloff, M., Russel, A. M. T., Geer, N., Nicoll, F. \& Smith, G. (2019). A multivariate evaluation of 25 proximal and distal risk-factors for 
gambling-related harm. Journal of Clinical Medicine, 8 (509), 1-15. https://doi. org/10.3390/jcm8040509.

5. Calado, F. \& Griffiths, M. D. (2016). Problem gambling worldwide: An update and systematic review of empirical research (2000-2015). Journal of Behavioral Addictions, 5 (4), 592-613. https://doi.org/10.1556/2006.5.2016.073.

6. Caler, K. \& Nower, L. (2016). Assessing problem gambling: A review of classic and specialized measured. Current Addiction Reports, 3 (4), 437-444. https:// doi.org/10.1007/s40429-016-0118-7.

7. Canale, N., Vieno, A., Griffiths, M. D., Rubaltelli, E. \& Santinello, M. (2015). How do impulsivity traits influence problem gambling through gambling motives? The role of perceived gambling risk/benefits. Psychology of Addictive Behaviors, 29 (3), 813-823. https://doi.org/10.1037/adb0000060.

8. Collins, D. \& Lapsley, H. (2003.). The social costs and benefits of gambling: An introduction to the economic issues. Journal of Gambling Studies, 19 (2), 123148. https://doi.org/10.1023/A:1023677214999.

9. Currie, S. R., Hodgins, D. C. \& Casey, D. M. (2013). Validity of the Problem gambling severity index interpretive categories. Journal of Gambling Studies, 29 (2), 311-327. https://doi.org/10.1007/s10899-012-9300-6.

10. Desai, R. A. \& Potenza, M. N. (2008). Gender differences in the associations between past-year gambling problems and psychiatric disorders. Social Psychiatry and Psychiatric Epidemiology, 43 (3), 173-183. https://doi.org/10.1007/ s00127-007-0283-z.

11. Dodig Hundrić, D. \& Ricijaš, N. (2019). The development and evaluation of the psychosocial treatment of problem gamblers in prisons. 7th International Conference on Pathological Gambling and Other Behavioral Addictions. Varšava. Poljska (18.-19.11.2019.)

12. Dodig, D. \& Ricijaš, N. (2011). Obilježja kockanja zagrebačkih adolescenata. Ljetopis socijalnog rada, 18 (1), 103-125.

13. Dowling, N., Suomi, A., Jackson, A., Lavis, T., Patford, J., Cockman, S., Thomas, S., Bellringer, M., Koziol-Mclain, J., Battersby, M., Harvey, P. \& Abbott, M. (2016). Problem gambling and intimate partner violence: A systematic review and meta-analysis. Trauma Violence Abuse, 17 (1), 43-61. https://doi. org/10.1177/1524838014561269.

14. Državni zavod za statistiku (2019.). Priopćenje, 7.1.3. Preuzeto s: https://www. dzs.hr/Hrv_Eng/publication/2019/07-01-03_01_2019.htm (28.11.2020.)

15. DSM-5 (2014). Dijagnostički i statistički priručnik za duševne poremećaje. Peto izdanje. Jastrebarsko: Naklada Slap.

16. Ferris, J. \& Wynne, H. J. (2001). The Canadian problem gambling index - Final report. Ottawa: Canadian Centre on Substance Abuse. 
17. Franzini, M. (2007). Social costs, social rights and the limits of free market capitalism: A re-reading of Kapp. In: Elsner, W., Frigato, P. \& Ramazzotti, P. (eds.), Social Costs and Public Action in Modern Capitalis, New York: Routledge, 68-83.

18. Gerstein, D., Volberg, R. A., Toce, M. T., Harwood, H., Johnson, R. A., Buie, T. \& Sinclair, S. (1999). Gambling impact and behaviour study: Report to the national gambling impact study commission. Chicago: National Opinion Research Center.

19. Glavak Tkalić, R., Miletić, G. M. \& Sučić, I. (2017). Igranje igara na sreću u hrvatskom društvu. Zagreb: Institut društvenih znanosti Ivo Pilar i Ured za suzbijanje zlouporabe droga Vlade Republike Hrvatske.

20. Griffiths, M. (2005). A 'components' model of addiction within a biopsychosocial framework. Journal of Substance Use, 10 (4), 191-197. https://doi. org/10.108014659890500114359.

21. Hing, N., Russell, A. \& Hronis, A. (2016). Behavioural indicators of responsible gambling consumption. Melbourne: Victorian Responsible Gambling Foundation.

22. Holtgraves, T. (2009). Evaluating the Problem gambling severity index. Journal of Gambling Studies, 25 (1), 105-120. https://doi.org/10.1007/s10899-008-9107-7.

23. Ibáñez, A., Blanco, C., Moreryra, P. \& Sáiz-Ruiz, J. (2003). Gender differences in pathological gambling. The Journal of Clinical Psychiatry, 64 (3), 295-301. https:// doi.org/10.4088/jcp.v64n0311.

24. Jaklič, M., Zagoršek, H., Pahor, M. \& Cvelbar, L. K. (2006). Analiza upravičenosti spremembe obdavčitve posameznih iger na srečo v Sloveniji: zaključno poročilo Študije igralniške dejavnosti: šifra: 4302-3/2006: naročnik Ministrstvo za finance. Ljubljana: Ekonomska fakulteta.

25. Kavli, H. \& Berntsen, W. (2005). Gambling habits and gambling problems in the population. Prepared for Norsk tipping, the Government gambling operator. Oslo: MMI Research.

26. King, D. L., Chamberlain, S. R., Carragher, N., Billieux, J., Stein, D., Mueller, K., Potenza, M. N., Rumpf, H. J., Saunders, J., Starčević, V., Demetrovics, Z., Brand, M., Lee, H. K., Spada, M., Lindeberg, K., Wu, A. M. S., Lemenager, T., Pallesen, S., Achab, S., Kyrios, M., Higuchi, S., Fineberg, N. A. \& Delfabbro, P. H. (2020). Screening and assessment tools for gaming disorder: A comprehensive systematic review. Clinical Psychology Review, 77, 101831. https://doi.org/10.1016/j.cpr.2020.101831.

27. Kristiansen, S. \& Jensen, S. (2011). Prevalence of gambling problems among adolescents in the Nordic countries: An overview of national gambling surveys 1997-2009. International Journal of Social Welfare, 20 (1), 75-86. https://doi. org/10.1111/j.1468-2397.2009.00701.x.

28. Loo, J. M. Y., Oei, T. P. S. \& Raylu, N. (2011). Psychometric evaluation of the problem gambling severity index - Chinese version (PGSI-C). Journal of Gambling Studies, 27 (3), 453-466. https://doi.org/10.1007/s10899-010-9221-1. 
29. Lorains, F. K., Cowlishaw, S. \& Thomas, S. A. (2011). Prevalence of comorbid disorders in problem and pathological gambling: Systematic review and meta-analysis of population surveys. Addiction, 106, 490-498, https://doi.org/10.1111/j.13600443.2010.03300.x.

30. Lovrinčević, Ž., Mikulić, D. \& Orlović, A. (2015). Ekonomski aspekti industrije poroka u Hrvatskoj. Društvena istraživanja, 24 (2), 175-196. https://doi.org/10.5559/ di.24.2.01.

31. Macur, M., Makarovič, M., Rončević, B., Vehovar, U. \& Zorec, K. (2008). Družbeni stroški igralništva v Sloveniji. Ljubljana: Fakulteta za uporabne družbene študije.

32. Magoon, M. E., Gupta, R. \& Derevensky, J. (2005). Juvenile delinquency and adolescent gambling: Implications for juvenile justice system. Criminal Justice and Behavior, 32 (6), 690-710. https://doi.org/10.1177/0093854805279948.

33. McCready, J. \& Adlaf, E. (2006). Performance and enhancement of the Canadian problem gambling index: Report and recommendations, Guelph, ON: Ontario Problem Gambling Research Centre.

34. Miller, N., Currie, S. R., Hodgins, D. C. \& Casey, D. (2013). Validation of the Problem gambling severity index using confirmatory factor analysis and rasch modelling. International Journal of Methods in Psychiatric Research, 22 (3), 245255. https://doi.org/10.1002/mpr.1392.

35. Ministarstvo financija (2020). Najznačajnije kategorije prihoda državnog proračuna prema računskom planu do prosinca 2019. Preuzeto s: https://mfin.gov. $\mathrm{hr} /$ pristup-informacijama/statistika-i-izvjesca/vremenske-serije-podataka/98 (5.6.2020.)

36. Ministry of Finance - Sweden (2019). Gambling act (2018:1138 Preuzeto s: https://www.spelinspektionen.se/globalassets/dokument/engelsk/oversatt-spellagen/english-spellagen-sfs-201_1138.pdf (27.11.2020.)

37. Ministry of Health (2009) A focus on problem gambling: Results of the 2006/07 New Zealand health survey. Wellington: Ministry of Health.

38. National Research Council (1999). Pathological gambling: A critical review. Washington, DC: The National Academies Press. https://doi.org/10.17226/6329..

39. Neal, P., Delfabbro, P. \& O'Neil, M. (2005). Problem gambling and harm: Towards a national definition. Melbourne: Gambling Research Australia.

40. Olason, D. \& Gretarsson, S. (2009). Iceland. In: Meyer, G., Hayer, T., Griffiths, M. (eds.), Problem gambling in Europe: Challenges, prevention, and interventions. New York: Springer, 137-152.

41. Orford, J., Wardle, H., Griffiths, M., Sproston, K. \& Erens, B. (2010). PGSI and DSM-IV in the 2007 British gambling prevalence survey: Reliability, item response, factor structure and inter-scale agreement, International Gambling Studies, 10 (1), 31-44. https://doi.org/10.1080/14459790903567132. 
42. Pahor, M. \& Cvelbar, L. K. (2006). Analiza upravičenosti spremembe obdavčitve posameznih iger na srečo v Sloveniji: Zaključno poročilo Študije igralniške dejavnosti: šifra: 4302-3/2006: naročnik Ministrstvo za finance. Ljubljana: Ekonomska fakulteta.

43. Petry, N. M. \& Armentano, C. (1999). Prevalence, assessment, and treatment of pathological gambling: A review. Psychiatric Services, 58 (8), 1021-1027. https:// doi.org/10.1176/ps.50.8.1021.

44. Productivity Commission (1999). Australia's gambling industries, Report No. 10. Canberra: AusInfo, Preuzeto s: https://www.pc.gov.au/inquiries/completed/ gambling/report/gambling1.pdf (10.12.2020.).

45. Reith, G. (2006). Research on the social impacts of gambling: Final report. Scottish Executive Social Research, Project Report. Edinburgh: Scottish Government.

46. Ricijaš, N. (2019). The development of psychosocial interventions for problem gamblers in Croatia - Social responsibility and interagency collaboration. The Value of Responsibility EL/WLA Seminar.

47. Ricijaš, N., Dodig Hundrić, D. \& Kranželić, V. (2015). Sportsko klađenje i druga rizična ponašanja hrvatskih srednjoškolaca. Hrvatska revija za rehabilitacijska istraživanja, 51 (2), 41-56.

48. Ricijaš, N., Dodig Hundrić, D., Huić, A., \& Kranželić, V. (2016). Kockanje mladih u Hrvatskoj - Učestalost igranja i zastupljenost problematičnog igranja. Kriminologija i socijalna integracija, 24 (2), 24-47. https://doi.org/10.31299/ksi.24.2.2.

49. Ricijaš, N., Maglica, T. \& Dodig Hundrić, D. (2019). Regulativa igara na sreću u Hrvatskoj kao socijalni rizik. Ljetopis socijalnog rada, 26 (3), 335-361. https:// doi.org/10.3935/ljsr.v26i3.297.

50. So, R., Matsushita, S., Kishimoto, S. \& Furukawa, T. A. (2019). Development and validation of the Japanese version of the problem gambling severity index. Addictive Behaviors, 98, 105987. https://doi.org/10.1016/j.addbeh.2019.05.011.

51. Sulkunen, P., Babor, T. F., Ornberg, J. C., Egerer, M., Hellman, M., Livingstone, C., Marionneau, V., Nikkinen, J., Orford, J., Room, R. \& Rossow, I. (2019). Setting limits - Gambling, science, and public policy. Oxford: Oxford University Press.

52. Sundqist, K. \& Rosendahl, I. (2019). Problem gambling and psychiatric comorbidity - Risk and temporal sequencing among women and men: Results from the Swelogs case-control study. Journal of Gambling Studies, 35 (3), 757-771. https://doi.org/10.1007/s10899-019-09851-2.

53. Šimović, H., Bajo, A., Primorac, M., Davidović, M. \& Jelavić, F. (2019). Tržište igara na sreću u Hrvatskoj: Financijsko poslovanje i fiskalni učinak. Fiskus, 9, 1-29. https://doi.org/10.3326/hfiscus.2019.9.

54. Volberg, R. A. \& Williams, R. J. (2012). Developing a short form of the PGSI. Report to the Gambling commission. Preuzeto s: https://www.gamblingcommission.gov. uk/PDF/survey-data/Developing-a-Short-Form-of-the-PGSI.pdf (24.11.2020.). 
55. Walker, D. M. \& Barnett, A. H. (1997). The social costs of legalized gambling reconsidered. Paper presented at the 10th International Conference on Gambling and Risk-Taking, Montreal, Quebec, (1-3.6.1997.).

56. Wardle, H., Reith, G., Best, D., McDaid, D. \& Platt, S. (2018). Measuring gambling-related harms - A framework for action. Gambling Commission. Responsible Gambling Strategy Board. Gamble Aware. Version: 0.5. Preuzeto s: https:// www.gamblingcommission.gov.uk/PDF/Measuring-gambling-related-harms.pdf (10. 12. 2020.)

57. Williams, R. J., Royston, J. \& Hagen, B. F. (2005). Gambling and problem gambling within forensic population: A review of the literature. Criminal Justice and Behavior, 32 (6), 665-689. https://doi.org/10.1177/0093854805279947.

58. World Health Organisation - WHO (2018). WHO releases new International Classification of Diseases (ICD 11). Preuzeto s: https://www.who.int/news-room/ detail/18-06-2018-who-releases-new-international-classification-of-diseases-(icd-11) (15.12.2020.).

59. Wynne, H. (2003). Introducing the Canadian Problem Gambling Index. Edmonton, AB: Wynne Resources.

60. Zakon o igrama na sreću (2009., 2013., 2014.). Narodne novine, 87/2009., 35/2013., 158/2013., 41/2014. 
Tomislav Globan

University of Zagreb

Faculty of Economics \& Business

Lucija Rogić Dumančić

University of Zagreb

Faculty of Economics \& Business

Neven Ricijaš

Sveučilište u Zagrebu

Faculty of Education and Rehabilitation Sciences

Mislav Ante Omazić

University of Zagreb

Faculty of Economics and Business

\section{ECONOMIC AND SOCIAL COSTS OF GAMBLING ADDICTION IN CROATIA - THE OTHER SIDE OF THE MEDAL}

\section{ABSTRACT}

Gambling, as a behavior primarily aimed at entertainment and leisure, is risky due to the potential development of harmful psychosocial consequences, i.e. the development of gambling addiction symptoms. These include the full range of health (physical and mental), social (family, friends, community), and economic (employment, finances, and crime) adverse consequences.

The aim of this research is to calculate the economic and social costs of gambling addiction in the Republic of Croatia in order to provide science-based indicators to encourage positive regulatory changes that would ensure a balanced market between profitable and risky elements of the gambling industry.

The research starts from the scientific research on the prevalence of gambling addiction in the adult Croatian population and the official data on revenues in the state budget from all gambling activities. Two of the most commonly used methodologies were used to calculate the social and economic costs: National Opinion Research Centre - NORC and Australian Productivity Commission - APC. The research uses original and strict criteria for the prevalence of gambling addiction. Regardless of the methodology used, the results show that the social costs of gambling addiction in Croatia account for between $34 \%$ and $77 \%$ of the total annual gambling revenue. 
The results were interpreted in the context of general guidelines for improving the policy of responsible gambling, with the aim of reducing the likelihood of developing harmful psychosocial consequences in society.

Key words: gambling; gambling addiction; economic costs; social costs; consequences

\section{(c) (1) ()}

Međunarodna licenca / International License:

Creative Commons Attribution-NonCommercial-NoDerivatives 4.0. 